Cultures de bêtes... Outils qui pensent?

\title{
Technologie et anthropologie
}

\section{Lucien Scubla}

\section{OpenEdition \\ Journals}

Édition électronique

URL : https://journals.openedition.org/tc/581

DOI : $10.4000 /$ tc. 581

ISSN : 1952-420X

\section{Éditeur}

Éditions de l'EHESS

\section{Édition imprimée}

Date de publication : 1 novembre 1995

ISSN : 0248-6016

\section{Référence électronique}

Lucien Scubla, «Technologie et anthropologie », Techniques \& Culture [En ligne], 23-24 | 1995, mis en ligne le 09 décembre 2005, consulté le 29 septembre 2022. URL : http://journals.openedition.org/tc/ 581 ; DOI : https://doi.org/10.4000/tc.581

Ce document a été généré automatiquement le 29 septembre 2022

Tous droits réservés 


\section{Technologie et anthropologie}

Lucien Scubla 